\title{
Post-zygotic reproductive isolation in two populations of the African vlei rat Otomys irroratus
}

\author{
Neville PILLAY*, Ken WILLAN and Jurgens MEESTER
}

Pillay N., Willan K. and Meester J. 1995. Post-zygotic reproductive isolation in two populations of the African vlei rat Otomys irroratus. Acta Theriologica 40: 69-76.

Post-zygotic reproductive isolating mechanisms between two chromosomally distinct, allopatric Otomys irroratus (Brants, 1827) populations (Kamberg and Karkloof) were studied in the laboratory by means of breeding trials, and by comparing the postnatal development of young of intrapopulation and interpopulation pairs. In contrast to the $100 \%$ breeding success of intrapopulation pairs, fewer than half of the interpopulation pairs produced young, and overall reproductive performance of these pairs was reduced. Furthermore, fitness of hybrids was dramatically impaired, as indicated by increased pre-weaning mortality, and inhibited growth in respect of body mass (postnatal development), as well as almost complete sterility (backcross and hybrid-cross matings) of surviving young. The results indicate the existence of chromosomal and/or genetic incompatibility between the two populations. The presence of a tandem fusion in the Kamberg karyotype is thought to be particularly significant in causing hybrid sterility, and the Kamberg population may be regarded as an incipient sibling species.

Department of Biology, University of Natal, King George V Avenue, Durban 4001, South Africa (NP, KW); Natal Sharks Board, Private Bag 2, Umhlanga Rocks 4320, South Africa (JM)

Key words: Otomys irroratus, breeding, postnatal development, speciation, reproductive isolating mechanisms

\section{Introduction}

By means of a series of laboratory breeding trials, Pillay et al. (1992) demonstrated the existence of reduced reproductive success among three chromosomally distinct allopatric populations (Committee's Drift, Hogsback, Karkloof) of the vlei rat Otomys irroratus (Brants, 1827) (Muridae, Otomyinae). Of significance in that study was that a high proportion of hybrids from interpopulation pairings involving Committee's Drift animals died before weaning, and that almost all hybrids from Hogsback-cross pairings were sterile. The presence of a tandem fusion in the Hogsback karyotype was apparently responsible for this sterility.

The results of the breeding study (Pillay et al. 1992) appeared to confirm the Meester (1988) model of chromosomal speciation, which postulates the formation

* Present address: Department of Zoology, University of the Witwatersrand, Private Bag 3, WITS 2050 , South Africa 
of sibling species as a consequence of chromosomal rearrangements which act as a post-zygotic reproductive isolating mechanism.

In the course of ongoing studies on speciation in populations of $O$. irroratus (see Meester et al. 1992), the interbreeding potential of two allopatric KwaZulu-Natal Midlands populations (Kamberg and Karkloof) was ascertained. These populations were selected for study on the basis of their close geographic proximity (i.e. less than $50 \mathrm{~km}$ apart), suggesting that gene flow between them is possible in nature (Pillay 1993). More importantly, the populations are karyotypically dissimilar, with a tandem fusion in the Kamberg cytotype (Contrafatto et al. 1992b) which is absent in the Karkloof karyotype (Contrafatto et al. 1992a). Hence, the study presented another opportunity to evaluate the Meester (1988) model, and allowed testing of the hypothesis that a tandem fusion may dramatically reduce hybrid breeding success (Pillay et al. 1992). In addition, chromosome and/or gene imbalances in hybrids are known to impair their growth and development (Dobzhansky and Levene 1951, Braverman et al. 1992), potentially rendering them inviable (Godfrey 1958, Lovecky et al. 1979); hybrid inviability (i.e. impaired development and/or failure to survive to adulthood) may act as a post-zygotic reproductive isolating mechanism (Mayr 1963). To ascertain whether or not hybrids in the present study were inviable, the postnatal development of young from intrapopulation and interpopulation pairs was compared.

\section{Materials and methods}

The populations represented in this study - Kamberg $\left(29^{\circ} 23^{\prime} \mathrm{S}, 29^{\circ} 42^{\prime} \mathrm{E}\right)$ and Karkloof $\left(29^{\circ} 17^{\prime} \mathrm{S}\right.$, $\left.30^{\circ} 11^{\prime} \mathrm{E}\right)$ - are characterised by the following karyotypes: Kamberg $-2 \mathrm{~N}=24-27$, all acrocentrics, tandem fusion between pairs seven and 12; Karkloof $-2 \mathrm{~N}=30-32$, all acrocentrics (Contrafatto et al. 1992a, b).

\section{Breeding}

Maintenance of laboratory stocks and the conditions under which breeding took place are described elsewhere (see Pillay et al. 1992). The breeding performance of 70 intrapopulation, 40 interpopulation, 48 backcross and 12 hybrid-cross pairs (specified below as male $\times$ female) was ascertained. Interpopulation trials comprised bi-directional pairings (i.e. pairings of a Kamberg male and Karkloof female, and of a Karkloof male and Kamberg female). Backcross trials comprised pairings between progeny resulting from interpopulation matings with individuals from the parent stocks. Hybrid-crosses comprised pairings between hybrids resulting from the same cross category. Except for the hybrids and some individuals used in intrapopulation breeding, all animals used in breeding trials were known breeders. For convenience, young of intrapopulation pairs are referred to as purebred and those of interpopulation pairs as hybrids.

Pairs were held together for a total of 150 days or until the birth of the third litter, whichever occurred earlier, but pairs that were unproductive after 80 days were separated. Cages were inspected daily and the general condition of the pairs was assessed; pairs that engaged in damaging fights were separated. After parturition, the cage bedding was examined for evidence of dead neonates. Post-mortem examination was confined to the external body surface of neonates. Surviving juveniles were allowed to remain with the parents for the first 30 days, and thereafter transferred to holding cages. 
The postnatal development of selected litters representing intra- and interpopulation pairs was studied (see below).

The following were recorded for each litter: date of birth, size, and pre-weaning infant mortality. The fecundity (here defined as the product of mean litter size and the number of litters born per 150 days) was calculated for each pair. The Mann-Whitney $U$-test (Sokal and Rohlf 1987) was used to test for significance between the data sets in respect of intrapopulation and interpopulation pairings (e.g. between Kamberg and Karkloof $\times$ Kamberg pairings).

\section{Postnatal development}

The postnatal development of 121 young representing 15 Kamberg, 22 Karkloof, 8 Kamberg $\times$ Karkloof and 10 Karkloof $\times$ Kamberg litters was studied. Young were measured (i.e. head-body, hind-foot, ear and tail lengths) and weighed every second day for the first two weeks of life, and at weekly intervals thereafter to 14 weeks of age. The timing of the following physical developmental events was also monitored: opening of the eyes; first response to auditory and olfactory stimuli, indicated by a startle reaction to sucking sounds and gentle blowing across the face by the observer; development of locomotor abilities; weaning; and sexual maturity, recorded in males when the testes descended into the scrotal sacs and were of adult size, and in females when the vagina first became perforate (Pillay 1990). In addition, observations were made on the development of patterns of amicable and agonistic behaviour among littermates, and between young and their parents.

\section{Results}

\section{Breeding}

The results of all breeding trials are summarized in Table 1. All intrapopulation pairs produced offspring. In contrast, interpopulation breeding success was reduced, with only $47.5 \%$ of pairs producing young. Moreover, males of 10 of the 12 unsuccessful Kamberg $\times$ Karkloof pairs (Table 1) attacked and seriously wounded their mates. No damaging fights were observed in any other pairing.

Backcross and hybrid-cross breeding were severely impaired. All 57 hybrids which survived beyond weaning (Table 1) were used in either or both backcross and hybrid-cross breeding trials, but only one hybrid (a Karkloof $\times$ Kamberg female paired with a Karkloof male) produced young. This represented an overall hybrid breeding success of $<2 \%$.

Both mean litter size and mean fecundity of the interpopulation pairs were significantly lower than those of the intrapopulation pairs.

While low pre-weaning mortality was characteristic of progeny of intrapopulation pairs (3.9-6.2\%), hybrids experienced increased mortality (26-37.5\%; Table 1 ). Moreover, 17 of the 25 hybrid neonates which died during the study were injured, suggesting that infanticide may have been the cause of death.

\section{Postnatal development}

The timing of the onset of growth and behavioural developmental phenomena of young in the present study was remarkably similar to those described for $O$. irroratus from the Transvaal Highveld (Davis and Meester 1981) and Eastern Cape Province (Pillay 1990); details of the postnatal development of $O$. irroratus 
Table 1. Reproductive data in respect of the pairings indicated. $n$ - sample size, $\bar{x}-$ mean, 2 SE given in brackets. ${ }^{1}$ product of mean litter size and the number of litters born per 150 days. ${ }^{2,3,4,5}$ significantly smaller at the $5 \%$ significant level (Mann-Whitney $U$-test) from appropriate values of the Kamberg and Karkloof intrapopulation pairings.

\begin{tabular}{|c|c|c|c|c|c|c|c|c|c|c|c|}
\hline \multirow[b]{2}{*}{ Pairings } & \multicolumn{2}{|c|}{ Matings } & \multicolumn{3}{|c|}{ Litter size } & \multicolumn{3}{|c|}{ Fecundity $^{1}$} & \multicolumn{3}{|c|}{ Pre-weaning mortality } \\
\hline & $n$ & success & $n$ & & $\bar{x}$ & $n$ & & $\bar{x}$ & $\begin{array}{c}\text { Total } \\
\text { young }\end{array}$ & $\begin{array}{c}\text { Number } \\
\text { diet }\end{array}$ & $\%$ \\
\hline \multicolumn{12}{|l|}{ Intrapopulation } \\
\hline Kamberg & 30 & 30 & 83 & 2.27 & $(0.17)$ & 30 & 6.40 & $(0.61)$ & 193 & 12 & 6.2 \\
\hline Karkloof & 40 & 40 & 105 & 2.47 & $(0.15)$ & 40 & 6.03 & $(0.61)$ & 256 & 10 & 3.9 \\
\hline Totals & 70 & 70 & 188 & 2.37 & $(0.11)$ & 70 & 6.19 & $(0.44)$ & 449 & 22 & 4.9 \\
\hline \multicolumn{12}{|l|}{ Interpopulation } \\
\hline Kamberg $\times$ Karkloof & 20 & 8 & 15 & 2.07 & $(0.45)^{2}$ & 8 & 4.14 & $(1.10)^{3}$ & 32 & 12 & 37.5 \\
\hline Karkloof $\times$ Kamberg & 20 & 11 & 28 & 1.89 & $(0.30)^{4}$ & 11 & 4.71 & $(0.58)^{5}$ & 50 & 13 & 26.0 \\
\hline Totals & 40 & 19 & 43 & 1.95 & $(0.25)$ & 19 & 4.47 & $(0.57)$ & 82 & 25 & 30.5 \\
\hline \multicolumn{12}{|c|}{ Backcrosses involving young of: } \\
\hline Kamberg $\times$ Karkloof & 24 & 0 & - & - & - & - & - & - & - & - & - \\
\hline Karkloof $\times$ Kamberg & 24 & 1 & 1 & 1.00 & - & 3 & 1.00 & - & 1 & 0 & 0.0 \\
\hline Totals & 48 & 1 & 1 & 1.00 & - & 3 & 1.00 & - & 1 & 0 & 0.0 \\
\hline \multicolumn{12}{|c|}{ Hybrid-crosses involving young of: } \\
\hline Kamberg $\times$ Karkloof & 6 & 0 & - & - & - & - & - & - & - & - & - \\
\hline Karkloof $\times$ Kamberg & 6 & 0 & - & - & - & - & - & - & - & - & - \\
\hline Totals & 12 & 0 & - & - & - & - & - & - & - & - & - \\
\hline
\end{tabular}

are available from these studies. In addition, the development of purebred and hybrid young in the present study was indistinguishable.

Of all the physical developmental parameters, only increase in body mass revealed differences between hybrid and purebred young, and therefore only body mass is considered here. Growth rates in respect of head-body, tail, hind-foot and ear lengths of all purebred and hybrid young were more or less identical to those of $O$. irroratus from the Transvaal Highveld (see Davis and Meester 1981).

In view of apparent sexual dimorphism in body mass in the Kamberg population (Pillay 1993), growth rates of male and female young are considered separately in Fig. 1a and $1 \mathrm{~b}$ respectively. Theoretical von Bertalanffy growth curves (von Bertalanffy 1960, Creighton and Strauss 1986) were fitted to the mean values representing increase in body mass of hybrid and purebred young of each sex (Fig. 1). Age-specific data for the growth curves were derived from the von Bertalanffy growth equation $\mathrm{W}_{t}=\mathrm{W}_{a}\left[1-e^{-k(t-t 0)}\right]^{3}$, where $\mathrm{W}_{t}-$ mass at time $t, \mathrm{~W}_{a}-$ asymptotic mass, $e$ - base of natural logarithms, $k$ - rate of change of mass increments, and $t 0$ - theoretical parameter indicating the commencement of growth. Table 2 provides the theoretical von Bertalanffy equations for increase in body mass of purebred and hybrid young. 
Fig. 1. Mass increase of males (a) and females (b) resulting from intrapopulation and interpopulation pairings. Mean values indicated with symbols, and fitted von Bertalanffy growth curves with lines. Sample size given in brackets. Kam = Kamberg, Kar $=$ Karkloof.
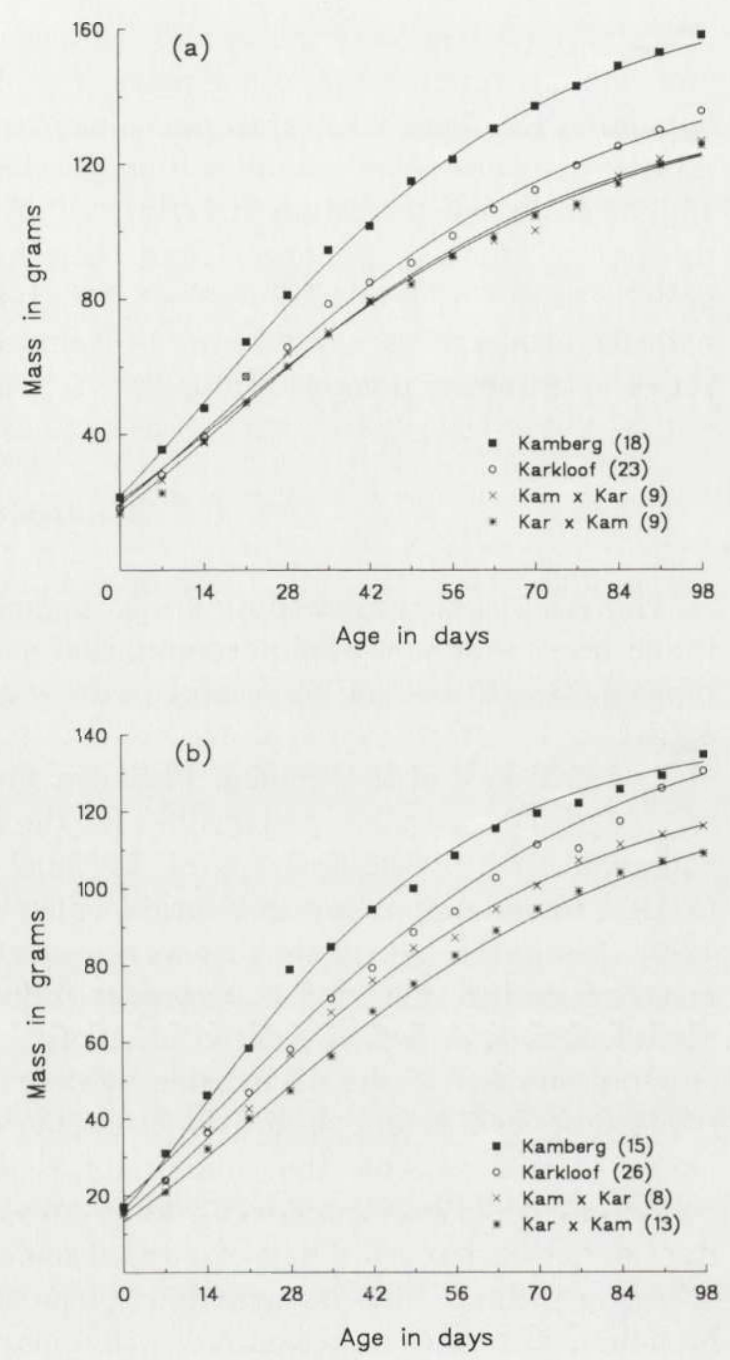

Table 2. Von Bertalanffy growth equations $\left(\mathrm{W}_{t}=\mathrm{W}_{a}\left[1-e^{-k(t-t 0)}\right]^{3}\right.$, see text for detail) for increase in body mass of males and females resulting from the pairings indicated. Sample sizes as in Fig. 1.

\begin{tabular}{lcc}
\hline Pairings & Males & Females \\
\hline Intrapopulation & & \\
$\quad$ Kamberg & $167.6\left[1-e^{-0.034(t+21.15)}\right]^{3}$ & $144.3\left[1-e^{-0.028(t+19.67)}\right]^{3}$ \\
Karkloof & $153.5\left[1-e^{-0.024(t+29.01)}\right]^{3}$ & $142.0\left[1-e^{-0.025(t+28.78}\right]^{3}$ \\
Interpopulation & & \\
Kamberg $\times$ Karkloof & $142.9\left[1-e^{-0.022(t+32.15)}\right]^{3}$ & $131.6\left[1-e^{-0.026(t+21.60)}\right]^{3}$ \\
Karkloof $\times$ Kamberg & $140.5\left[1-e^{-0.022(t+27.67)}\right]^{3}$ & $130.3\left[1-e^{-0.023(t+27.37)}\right]^{3}$ \\
\hline
\end{tabular}


At all ages Kamberg males and females were respectively heavier than males and females produced by other pairs (Fig. 1). Except for the pre-weaning development of Kamberg $\times$ Karkloof males which was similar to that of Karkloof males, all hybrids were always smaller than purebred young (Fig. 1). This observation is supported by consideration of estimates of asymptotic mass which suggest that the parent types grow larger than their hybrids (Table 2). In addition, slower growth rates (i.e. lower $k$ values of the growth equations) were recorded for the hybrids, although the growth rate of Kamberg $\times$ Karkloof females was within the range of purebred females (Table 2).

\section{Discussion}

The results of the breeding study suggest reduced fertility at the interpopulation level: $>50 \%$ of the interpopulation pairs failed to produce young, while the reproductive fitness of successful pairs was lower compared to intrapopulation pairs.

The presence of the tandem fusion in the Kamberg karyotype (Contrafatto et al. 1992b) was possibly responsible for the severely reduced breeding success of backcross and hybrid-cross pairs. Matings in which one of the parents has a tandem fusion may result in hybrids which have impaired gametogenesis (Moritz 1986). Similarly, hybrid sterility as a result of a tandem fusion has been reported in other studies involving $O$. irroratus (Pillay et al. 1992), and in a study of the dik-dik Madoqua kirki (Ryder et al. 1989).

Only one out of the 57 hybrids used in backcross and hybrid-cross breeding trials produced young, indicating that more than $98 \%$ of hybrids were sterile. However, it is possible that some hybrids would not have inherited the tandem fusion and could have produced young. Also, it may be assumed that hybrids with the tandem fusion could have produced some viable gametes, and would have had breeding success. This is particularly true of those hybrids involved in backcross breeding, since these were paired with apparently fertile mates; in hybrid-crosses, both hybrids could have produced unbalanced gametes, reducing the chances for successful breeding. Therefore, it may be argued that other factors, either on their own or in combination with the tandem fusion, were responsible for hybrid sterility. The literature suggests that morphological defects (inter alia Mayr 1963) and/or physiological and behavioural abnormalities (inter alia Dobzhansky et al. 1968) of the hybrids also might have contributed to their reduced mating success.

Unlike the case in the hybrids, viable and fertile young were produced by intrapopulation pairings involving mates with different cytotypes (e.g. between $2 \mathrm{~N}=24$ and $2 \mathrm{~N}=27$ Kamberg individuals, and between $2 \mathrm{~N}=30$ and $2 \mathrm{~N}=32$ Karkloof individuals). These differences in diploid number reflect intrapopulation variation in the number (from 0 to 3 ) of copies of a pair of B-chromosomes (Contrafatto et al. 1992b). With some exceptions, the influence of B-chromosomes 
on the phenotype is negligible (Volobujev 1981, Jones and Rees 1982), and it was predictable that phenotypically and reproductively fit purebred offspring would have been produced by cytotype-cross pairings.

Hybrid inviability, exemplified by comparatively high pre-weaning mortality and inhibited growth in the hybrids, may have been caused by defective chromosome and/or gene configurations, as reported for species of Drosophila (Dobzhansky and Levene 1951, Dobzhansky et al. 1968, Orr 1990, Braverman et al. 1992). In addition to the potential effects of disruption of co-adapted gene or chromosomal complexes during hybridization (e.g. biochemical and physiological breakdown; Dobzhansky and Levene 1951, Rogers and Dawson 1971, Burton 1990), maladaptive behaviour by unweaned young may result in their being rejected and/or killed by the mother (Conley and Bell 1978, Harper 1981), which may have accounted for the high incidence of infanticide in crossbred young.

High levels of aggression which resulted in damaging fights necessitated separation of approximately half of the Kamberg $\times$ Karkloof pairs. Such aggressive interaction was apparently due to impaired recognition by either or both sexes of the courtship behaviour of the other individual (Pillay 1993, Pillay et al., in press).

Lower hybrid fitness (i.e. hybrid sterility and inviability) may function as a post-zygotic reproductive isolating mechanism should the Kamberg and Karkloof populations meet in nature. Like other $O$. irroratus populations (e.g. Hogsback; Pillay et al. 1992), the presence of the tandem fusion in the Kamberg karyotype may have caused a breakdown of reproduction, and the Kamberg population may be regarded as an incipient sibling species (Meester 1988). However, this conclusion requires testing by means of cytological studies of the gametes of hybrids.

Acknowledgements: We thank S. Govender, K. Govindsamy, D. Padiachy and S. Shezi for technical assistance, R. Parker for providing some of the Karkloof animals, the Natal Parks Board, in particular D. Rowe-Rowe, for permission to collect animals from Kamberg Nature Reserve, and J. Cooke, G. Contrafatto and P. Taylor for commenting on the manuscript. Financial support from the University of Natal and the Foundation for Research Development is gratefully acknowledged.

\section{References}

Bertalanffy L., von 1960. Principles and theory of growth. [In: Fundamental aspects of normal and malignant tumours, W. W. Nowinski, ed]. Elsevier, Amsterdam: 137-259.

Braverman J. M., Goni B. and Orr H. A. 1992. Loss of paternal chromosome causes developmental anomalies among Drosophila hybrids. Heredity 69: 416-422.

Burton R. S. 1990. Hybrid breakdown in physiological response: a mechanistic approach. Evolution 44: 1806-1813.

Conley L. and Bell R. W. 1978. Neonatal ultrasounds elicited by odor cues. Developmental Psychology 11: 193-197.

Contrafatto G., Meester J. A., Willan K., Taylor P. J., Roberts M. A. and Baker C. M. 1992a. Genetic variation in the African rodent subfamily Otomyinae (Muridae). II: Chromosomal changes in some populations of Otomys irroratus. Cytogenetics and Cell Genetics 59: 293-299. 
Contrafatto G., Meester J., Bronner G. and Willan K. 1992b. Genetic variation in the African rodent subfamily Otomyinae (Muridae). IV: Chromosome G-banding analysis of Otomys irroratus and O. angoniensis. Israel Journal of Zoology 38: 279-293.

Creighton G. K. and Strauss R. E. 1986. Comparative patterns of growth and development in cricetine rodents and the evolution of ontogeny. Evolution 40: 94-106.

Davis R. M. and Meester J. 1981. Reproduction and postnatal development in the vlei rat, Otomys irroratus, on the Van Riebeeck Nature Reserve, Pretoria. Mammalia 45: 99-116.

Dobzhansky T. and Levene H. 1951. Development of heterosis through natural selection in experimental populations of Drosophila pseudoobscura. American Naturalist 85: 247-264.

Dobzhansky T., Erhman L. and Kastritsis P. A. 1968. Ethological isolation between sympatric and allopatric species of the Obscura group of Drosophila. Animal Behaviour 16: 79-87.

Godfrey J. 1958. The origin of sexual isolation between bank voles. Proceedings of the Royal Physical Society of Edinburgh 27: 47-55.

Harper L. V. 1981. Offspring effects upon parents. [In: Parental care in mammals, D. J. Gubernick and P. H. Klopfer, eds]. Plenum Press, New York: 117-177.

Jones R. N. and Rees H. 1982. B chromosomes. Academic Press, London: 1-266

Lovecky D. V., Estep D. Q. and Dewsbury D. A. 1979. Copulatory behaviour of the cotton mice (Peromyscus gossypinus) and their reciprocal hybrids with white-footed mice (P. leucopus). Animal Behaviour 27: 371-375.

Mayr E. 1963. Animal species and evolution. The Belknap Press of Harvard University Press, Massachusetts: 1-797.

Meester J. 1988. Chromosomal speciation in southern African small mammals. South African Journal of Science 84: 721-724

Meester J., Taylor P. J., Contrafatto G-C., Campbell G. K., Willan K., Lamb J. M. and Pillay N. 1992. Chromosomal speciation in Southern African Otomyinae (Rodentia: Muridae): a review. Durban Museum Novitates 17: 58-63.

Moritz C. 1986. The population biology of Gehydra (Gekkonidae): chromosome change and speciation. Systematic Zoology 35: 46-67.

Orr H. A. 1990. Developmental anomalies in Drosophila hybrids are apparently caused by loss of microchromosome. Heredity 64: 255-262.

Pillay N. 1990. The breeding and reproductive biology of the vlei rat Otomys irroratus. M. Sc. thesis, University of Natal: 1-151.

Pillay N. 1993. The evolution and socio-ecology of two populations of vlei rat Otomys irroratus. Ph. D thesis, University of Natal: 1-214.

Pillay N., Willan K. and Meester J. 1992. Post-zygotic reproductive isolation in the African vlei rat Otomys irroratus (Muridae: Otomyinae). Israel Journal of Zoology 38: 307-313.

Pillay N., Willan K., Meester J. and Cooke J. (in press). Evidence of pre-mating reproductive isolation in two allopatric populations of the vlei rat Otomys irroratus. Ethology.

Rogers J. F. and Dawson W. D. 1971. Foetal and placental size in a Peromyscus species cross. eournal of Reproduction and Fertility 21: 255-262.

Ryder O. A., Kumamoto A. T., Durant B. S. and Benirschke K. 1989. Chromosomal divergerce and reproductive isolation in dik-diks. [In: Speciation and its consequences, D. Otte and J. A. Indler, eds]. Sinauer Associates Inc. Publishers, Sunderland: 208-225.

Sokal R. R. and Rohlf F. J. 1987. Introduction to Biostatistics, 2nd Ed. W. H. Freeman and Company, New York: 1-363.

Volobujev V. T. 1981. B-chromosomes system of the mammals. Caryologia 34: 1-23.

Received 16 February 1994, revised 28 December 1994, accepted 6 January 1995. 